\title{
Someone Has to Do It: Towards A Practical Defence of Politicians
}

\section{Jack Corbett}

Research Fellow

Centre for Governance and Public Policy and the Griffith Asia Institute

Griffith Business School

Building (N72), Room -1.07, Nathan campus, Griffith University

170 Kessels Road, Nathan QLD 4111, Australia

jack.corbett@griffith.edu.au

Phone: + 61737353732

And

Visiting Fellow

School of International, Political \& Strategic Studies

ANU College of Asia \& the Pacific

Australian National University

Canberra ACT 0200, Australia

jack.corbett@anu.edu.au

Phone: +61261258394

Biography: Jack Corbett is a Research Fellow at Griffith University's Centre for Governance and Public Policy and the Griffith Asia Institute. He is the author of Being Political:

Leadership and Democracy in the Pacific Islands (University of Hawaii Press) and several published or forthcoming articles on anti-politics and the demonization of politicians in journals such as the Journal of European Public Policy, Political Studies Review and Policy Studies.

* A slightly amended version of this paper is forthcoming in Contemporary Politics 21:4 (December 2015). 


\title{
Someone Has To Do It: Towards A Practical Defence Of Politicians
}

\begin{abstract}
In response to rising popular disenchantment with elected officials numerous scholars have sought to defend politics and restate why it matters. For the most part, however, these theoretical arguments overlook the views and reflections of politicians themselves. As a step towards filling this gap I survey politician-centred studies from around the world and the reflections of academics that have become politicians. By paying careful attention to what 'insiders' say about life in politics I construct a practical rather than theoretical defence of the vocation and the people who undertake it. I argue that politician's views remind us that human endeavour is central to the purpose and function of politics and associated political institutions. To link the practical views and experiences of politicians with the emerging literature on demonization I revisit the work of Arendt and Weber. I conclude that while we may not always like who politicians are or the ways they operate, revaluing endeavour allows us to give credit where credit is due; politicians may regularly disappoint us but representative democracy does not work without them.
\end{abstract}

Keywords: anti-politics, demonization, public disengagement, moral panic, democracy, leadership

\section{Introduction}

Popular disenchantment with the actions and conduct of politicians is becoming commonplace around the world, with numerous forms of public opinion polling confirming what most of us experience anecdotally: widespread consensus, reinforced with each new misdemeanour, that politicians do not deserve our trust or respect (for discussion see Flinders, 2012a, pp. vii-x; Stoker, 2006, pp. 1-7; Hay, 2007, pp. 11-39; Evans, Stoker \& Nasir, 2013). The phrase 'that's politics' typifies much of the fatalism that surrounds popular 
perceptions of the contemporary political world, reflecting the commonly held belief that all politicians act a certain way, and that politics has a fixed and unchangeable nature that is inherently compromised, dishonest, hypocritical and corrupt. In mild forms, democratic theorists argue, a level of popular cynicism towards authority can hold leaders to account. However, increasingly, scholars and public commentators have become concerned that demonisation has reached levels that threaten the function of democratic government as we know it. For some, particularly those who seek more participatory or deliberative forms of democratic practice, this is a welcome development that promises reflection and reform (Chambers 2003; Dryzek 2000; Fung \& Wright 2001; Gutmann \& Thompson 1996). Others, who strive to revive the themes of Bernard Crick's (2000) famous defence of politics, are concerned with the capacity for widespread disillusionment to erode popular sovereignty and replace it with technocratic or market-based decision-making mechanisms (Flinders 2012a; Hay 2007; Stoker 2006).

Normative implications aside, in seeking to understand the causes of this phenomenon a recent review of the literature identifies two dominant explanations ([omitted]; see also Flinders 2012b\&c and responses published in this journal). In the first, the demonization of politicians is conceptualised as a growing 'gap' between the expectations of citizens and the performance of politicians. In advancing this 'gap' view of demonization, scholars tend to favour either a 'demand-side' explanation - an ill-informed and apathetic public engage with an increasingly dumbed-down body politic - or a 'supply-side' account - politicians and political elites are not what they used to be (Hay \& Stoker 2009). Gerry Stoker (2006) and Colin Hay (2007), among others, advocate a 'supply-side' view, citing professional politicians, and the neo-liberal reforms they initiate, as root causes of anti-politics. In response to the proliferation of opinion polling that highlights low levels of public confidence in elected officials, they propose reclaiming popular participation in decision-making as an 
antidote that will revitalise our faith in politicians as 'amateurs' (Hay 2009). The alternate 'demand-side' perspective is most forcefully advanced by Matthew Flinders (2012a) who places much of the blame for anti-political sentiment at the feet of a 'bad faith model of politics' which is driven by a disengaged and ill-informed public who have decadent expectations about what politicians should and can deliver. In this view, politicians become 'folk devils' whose public demonization is consistent with other forms of moral panic (Flinders 2012b; see also Wood and Flinders 2012; Hatier 2012)

The main alternative to the 'gap' view of demonization is the 'trap' account in which politicians are wedged trying to fulfil the contradictory demands of democratic publics. The most common is the 'Leader-Follower Trap', as Kane and Patapan (2012, p. 44) highlight:

Thus, electors want their leaders to be just like them but also much better than them. They want a genuinely great leader who is nevertheless humble and has the 'common touch.' They want somebody who will do their bidding, listen to them, and not break promises, yet they will hold in contempt the leader who merely follows the polls, has no 'vision', and refuses to make tough, unpopular decisions.

Other traps, Stephen Medvic (2013) argues, include 'The Principled-and-Pragmatic Trap' where we want politicians to hold firm to their beliefs - we decry opportunism - and yet at the same time compromise to solve problems, and 'The Ordinary-and-Exceptional Trap' where we want to be represented by people like us, so they can understand us, but also better than us, so they can rule over us legitimately.

Both conceptualisations have their strengths. By emphasising the role of the media and neoliberal reform in particular the 'gap' view helps us to understand what has changed and by extension why the demonization of politicians is on the rise. By contrast, the 'trap' view reminds us that much remains constant. Politicians have never been popular and current 
discontent often stems from the irreconcilable tension between the democratic principle of popular sovereignty, where all people are equal, and the need for leadership (Kane and Patapan 2012). What this latter perspective in particular reminds us is that at times, when the weight of popular disenchantment rises and demonization reaches levels that appear to undermine the exercise of sound government, politicians are going to need some sort of defence. Such a defence may not solve the problem - fully closing the 'gap' or springing the 'trap' may not be possible - but both views hold out the possibility that a sympathetic counter-narrative can temper the destructive cycle where naive hope is inevitably replaced by cynical despondency as each new leader fails to meet expectations. Indeed, one irony of the strong adversarialism encouraged by democratic politics is that politicians are often the most vocal critics of politicians and so leaders who engage in apologetics tend to be dismissed as either self-serving or hypocritical. As a result, as Peter Riddell (2011) reminds us, any defence will need to be undertaken 'in spite of themselves'.

Bernard Crick (2000) but more recently Flinders (2012a) and others (Riddell 2011; Medvic 2013) have already instigated a defence of politics and politicians. By and large, however, in making their case they have tended to overlook the views of politicians themselves. That is, while the above authors point to the humanity of political actors when making a case in their defence, rarely do they draw on their reflections about what being a politician is like. This is a significant omission ([omitted]). Given that politicians are the subjects of this popular sentiment, it seems counter-productive that we continue to omit their views entirely from our discussion of it. Let me be clear, I am not saying that we would want to solely rely on the reflections of politicians on a topic like this. Rather, given that the views of citizens have been extensively surveyed, and theoretical work of the type discussed here is becoming increasingly thorough, the time has come to also canvass the views and reflections of 
politicians. Their reflections can only provide one-side of an inherently complex story, but, given that the story is about them, it is important to hear their version of it.

As an initial step towards filling this gap, I ask what being in politics is like from the perspective of those who undertake the job. My aim is to construct a counter-narrative based on the views of politicians about the work they do that extends the emerging anti-politics debate. I draw on two sources: 1) the small political studies literature that explores the meanings and beliefs that politicians attach to their jobs (for selected examples see Barber 1965; Fenno 1978; Headey 1974; King 1974; Mahler 2011; Reeher 2006; Rhodes 2011; Searing 1994; Tiernan \& Weller 2010; Walter 2006; Weller \& Grattan 1981); and 2) a selection of recent work by contemporary scholars who, on leaving public office, have documented their reflections (see McDonough 2000; Volgy 2001; French 2012; Ignatieff 2013). ${ }^{1}$ By listening carefully to what politicians say and staying close to what they do, these works blur the distinction between scholar and subject, and in doing so provide a sense of what it is like to be a politician. I contend that this 'inside' view can add an, as yet unexplored, human dimension to the current debate.

To link the practical views and experiences of politicians with the literature on the demonization of politicians I revisit the work of Arendt and Weber. Arendt's conceptualisation of Action values the humanity of the public sphere. I argue that this view of political life, based as it is on plurality and natality, helps us to break down the popular perception of politicians as exclusively self-interested and power hungry. Weber, by contrast, is more concerned with the hard grind of policymaking and the need for politicians in modern states to bore through 'hard boards'. It helps us understand why politicians often fail to meet

\footnotetext{
${ }^{1}$ Aside from these studies, the most extensive literature on politicians as people is political biography, a genre explicitly concerned with the uniqueness of the human experience. I do not deal extensively with the potential contribution of this genre here (but see examples where I [omitted] and others like Mahler [2006]; Scalmer \& Hollier [2009]; Shamir, Dayan-Horesh \& Adler [2005] have employed these texts for this purpose).
} 
expectations, and provides a rationale for why they must persist despite the odds. Combined, both Arendt and Weber point us to the centrality of human endeavour to the purpose and function of political life. Human endeavour is also the theme that emerges most strongly from the empirical material canvassed below. So, by drawing on the findings of scholarship that documents the views and reflections of politicians about their work I knit these seemingly divergent theoretical arguments together.

When combined, this analysis forms a 'counter narrative' (see Bamberg and Andrews, 2004; Rudd, 2009) to the commonly cited stereotypes. I argue that:

(1) Demonisation stems from the homogenisation of the group, which sits in contrast to the different types of people who enter parliament;

(2) Contrary to the perception of rampant self-interest, politicians tend to believe that virtuous motivations led them to the legislature, and claim that public service offers intrinsic rewards;

(3) We underestimate the fact that political life incurs great personal costs, including to family, health and business and professional careers; and

(4) Despite popular claims to the contrary (publically often espoused most strongly by politicians), policy making is actually beset with endless problems of contingency and uncertainty.

Before I flesh out both the theoretical and empirical arguments in more detail, let me briefly offer a few caveats. First, the empirical work that I draw upon here is illustrative rather than exhaustive. My aim is to provide a flavour of what being a politician is like that complements the theoretical discussion. The available material on or about politicians largely comes from Northern America, the United Kingdom and Australia and so limits my geographic 
coverage. ${ }^{2}$ However, as my own recent interview-based work on politicians and political life in the Pacific Islands demonstrates ([omitted]), disaffection with politicians appears to transcend cultures and institutional types, and so there is no reason to believe that this counter narrative could not be extended beyond the Anglo-sphere. In analysing these texts I have relied on an abductive logic (Schwartz-Shea and Yanow 2012); moving back and forth between the views and experiences of politicians and the puzzles and questions that dominate the existing literature. The sample is not 'representative' in the positivist sense and so does not lend itself easily to coding or other forms of quantitative analysis. However, all sources are publically available and thus can be read by anybody seeking to corroborate the patterns and themes that I have identified.

Second, the material that I draw upon was, for the most part, designed to answer different questions to the ones posed here. Perhaps unsurprisingly, all authors tend to provide a sympathetic portrayal of politicians and political life. But, with the exception of Reeher (2006), they have not explicitly linked their material to the anti-politics debate. This article is premised on the belief that this body of work has much to offer this discussion. However, in linking the literatures on what being a politician is like and popular disaffection with their role I acknowledge that I am providing my interpretations of these actors and authors' interpretations (Hay 2011). Only further empirical work can parse this out and I report on the findings of my own attempts elsewhere ([omitted]). For now, however, my aim is to outline a theoretical basis for making this move and to demonstrate the types of empirical insights relevant to growing debate about anti-politics and politicians that this type of research can generate.

\footnotetext{
${ }^{2}$ Obviously, there is great variety in the types of political institutions found across these countries. Each also has different subsidiary governance arrangements that include various forms of state and local jurisdictions. The reflections contained here are drawn from across these typical intellectual divides. Where necessary I draw out distinctions between Westminster systems or professionalized versus unprofessionalised politics, for example. For the most part, however, these differences have little bearing on the overall case I seek to make.
} 


\section{Why Somebody Has to Do It: Theorising the Value of Human Endeavour}

Embedded within each of the above points is an argument about the centrality of human endeavour - defined here as the willingness of politicians to participate - to the purpose and function of politics and associated institutions. In a famous speech delivered on April 23, 1910, former President of the United States of America, Theodore Roosevelt, provided the following comment on the importance of participation in public life:

It is not the critic who counts: not the man who points out how the strong man stumbles or where the doer of deeds could have done better. The credit belongs to the man who is actually in the arena, whose face is marred by dust and sweat and blood, who strives valiantly, who errs and comes up short again and again, because there is no effort without error or shortcoming ... (cited in Flinders 2010, p. 325).

Roosevelt's insights about the underlying significance of human endeavour in the political realm draw our attention to both the extraordinary and mundane aspects of a life dedicated to political action.

This recognition is not entirely novel; despite the clichéd symbiosis of philosophy and reflection, some theorists have made the case for why active participation matters. One of the most distinct enunciations can be found in the work of Hannah Arendt and The Human Condition (1958) in particular. Arendt famously preferred the term Action to outline what was unique about political life, which she defined in opposition to the concepts Labour and Work; the essence of which is instrumental, involving sustenance and production whereas Action is distinctly political. It is a fundamentally human activity based on two features of the human condition: natality and plurality. Natality recognises the capacity of people to start something new as the very act of being born signifies the possibilities and unexpectedness of new beginnings and our ability to interrupt routines by stepping forth into the public realm. 
Plurality refers to our essential sameness - we are all human - but also difference - each person has a unique biography that cannot be interchanged with another's (Arendt, 1958, p. 8).

Combined, natality and plurality underpin what Arendt considers to be distinctive about Action. For Arendt, politics is the constitution of personhood via the public realm. It is a performative (speech bestows dignity on politics) and therefore fundamentally human activity based on the mutual need for association that can only come from the company of others (Schaap, 2012, p. 149). That is, we cannot know who we are unless we interact with others and this ultimately drives the creation and maintenance of public spaces:

Political institutions, no matter how well or how badly designed, depend for continued existence upon acting men; their conversation is achieved by the same means that brought them into being. Independent existence marks the work of art as a product of making; utter dependence upon further acts to keep it in existence marks the state as a product of action (Arendt 1961: 153).

In the context of the anti-politics debate, Arendt's (1958) celebration of Action places extraordinary value on the distinctively human dimension of political life that, for the purposes of this article, we can juxtapose with the suspicion that the motivations of commonly politicians attract.

Arendt's theory of action points to the sense of glory articulated in Roosevelt's conceptualisation of human endeavour. The 'arena', from this perspective, offers the 'doer of deeds' worldly immortality in a way that more mundane aspects of life - Labour and Work do not; actions in the public realm are remembered long after the products of Labour and Work have disappeared. On the other hand, Arendt is in many ways a strange match for this article as she explicitly seeks to distance Action from the second part of Roosevelt's 
statement - the tedious necessity of the daily grind - which she might dismiss as mere Work (Schaap, 2012, p. 151). Indeed, Arendt preferred more localised and deliberative forms of active citizenship to the current mode of representative government. Arendt, then, can only take us so far. In order to flesh out the second aspect of Roosevelt's articulation of human endeavour we must turn to another $20^{\text {th }}$ century theorist: Max Weber.

The aspect of Weber's (1978, p. 225) work on politicians of most relevance to this discussion is his famous belief that politics as a vocation requires of its practitioners a commitment to 'boring down strongly and slowly through hard boards'. If Arendt points us to the promise of glorious deeds, Weber reminds us of the sober realities; in Roosevelt's 'blood, sweat and tears'. Endeavour, for Weber, is synonymous with effort. It can be heroic but in a more fatalistic way:

Only someone who is confident that he will not be shattered if the world, seen from his point of view, is too stupid or too vulgar for what he wants to offer it; someone who can say, in spite of that, 'but still!' - only he has the 'vocation' for politics (Weber 1978, p. 225).

Unlike Arendt, whose critique of modernity is grounded in a celebration of antiquity, Weber's conceptualisation of politics as a vocation is made for modern times and the nationstate in the particular. He values new beginnings - his tripartite leadership model extols the capacity of charismatic domination in particular - but ultimately sees politics as cyclical and recurrent rather than unexpected and contingent: revolution gives way to tradition which begets legal-rational authority. Indeed, where Arendt considers Action to have intrinsic meaning, reflecting his interest in the type of politician required to enable the modern statebased system, Weber places greater emphasises on the perseverance required to sustain the hard grind of political life. He is willing to accord leaders great latitude in their actions 
providing they succeed in achieving certain ends (if they fail he expects them to face severe consequences), but leaves little room for the failure and human frailties implied in Roosevelt's recognition that politicians strive but invariably come 'up short again and again'.

Combined, these two sides of life in politics, as canvased in this brief discussion, are revealed in Roosevelt's description of human endeavour that, for my purposes here, captures both the glorious and sober aspects of being a politician. It is a view that challenges reductive accounts that assume our leaders have fixed preferences that revolve around the acquisition of personal power, wealth and prominence. In service of a practical defence of politicians, an emphasis on participation highlights the corresponding importance of human values, like passion, duty and honour, which emerge strongly from the descriptions of politicians about their job, to political life. In addition to providing a contribution to the existing literature on anti-politics, endeavour highlights the human dimension of political practice. While it does not ignore the way existing social structures and inequalities dictate who can win elections, it offers one way of restoring a degree of respect to the people who do.

Revaluing endeavour will not solve all popular cynicism - to this extent I accept Kane and Patapan's (2012) view that it is an intractable feature of democratic government - but it does deflect the most excessive criticisms directed at politicians by providing a counter narrative which does not entirely hinge on a dichotomous distinction between moral purity and destructive self-interest; real people are neither saints nor sinners. Significantly, it allows us to recognise that the demonisation of politicians partly reflects our own discomfort with their function in a democratic system and our unwillingness to undertake the job ourselves. So, a practical defence of politicians rests upon the value of their willingness to participate and the concession that while we may not always like our politicians or the way they operate at the 
very least we must continually remind ourselves that representative democracy does not function without them.

\section{A Practical Defence of Politicians}

Respect for the humanity of political actors is often an anathema to academic debates about politicians and political leadership. These discussions tend to reduce the political experience to categories like class, to explain motivations on the basis of incentives and institutions, and to explore recruitment and retention through prisms like 'elite distinction'. A reminder that politicians are people, while somewhat axiomatic, is nevertheless important given that it is often overlooked by academics and other political commentators. Or, on the rare occasions that their humanity is acknowledged, it usually serves as a cue to discuss how petty, jealous, spiteful and incompetent politicians can be. In contrast, four arguments emerge from the relatively small political studies literature that explores the meanings and beliefs of politicians about their job. As with all such exercises there remains a degree of overlap between analytic categories designed to convey parsimony over the messy and unpredictable world of political practice. But, putting these endogenous limitations aside, this synthesis serves to ground the above theoretical discussion in the experience of everyday political life.

\section{Political Types}

The first counter argument that we find in this body of work is that disillusionment stems from the homogenisation of politicians as a group, which can be contrasted with the different types of people who enter parliament. One consequence of rising professionalization trends is a narrowing of career backgrounds amongst the political class that, some argue (e.g. Wright 2013), creates a gap between leaders and the led in terms of life experience. In contrast, John Uhr (2005) argues that there is no standard MP and the temptations, vices and virtues of politicians vary according to their role. In this respect generic terms like 'politician', 
'political elite', 'political class', 'legislator' and 'parliamentarian' provide a sense of uniformity that, channelling Arendt, belies the plurality of individuals who hold public office, their stories and experiences.

In their study of Australian ministers, Weller and Gratten (1981) provide a sense of this diversity when they identify the divergent views that politicians hold about civil servants, for example. For some, the caricature of an unresponsive and obstructionist bureaucracy that impedes the government of the day prevails, as this quote highlights:

Each department has its own policy and anything else is inferior by definition. I don't think I ever saw any policy options from my departments.

While for others, politicisation is a growing trend:

Sometimes I think they are too responsive. They are not enough prepared to argue with me.

These short extracts reveal the different experiences of ministers and their differing beliefs about what the civil service can and should be. Even as professionalization trends among the political class increase, and reforms commonly known as new public management are rolled out across the globe, these differences are apparent, as the updated version of that study shows (Tiernan and Weller 2010).

The other assumption that underpins the professionalization tag is that all politicians are 'careerists' and are therefore more concerned with their own job security than the people they represent. However, whilst education and career backgrounds may be becoming similar, studies of politicians demonstrate that the interests and objectives of leaders are often incredibly diverse. As a group, politicians hold varying ideological beliefs, preference certain policy issues over others, and have fluctuating career ambitions. Contrary to popular opinion, 
not all politicians seek to be cabinet ministers, prime ministers or presidents while others enter politics by chance or reluctantly. Indeed, the experiences of those politicians working in local or state government, where the profile is less but the demands of the job more time consuming, especially when undertaken part-time, bears this point out:

He said, "That's not really the reason I'm calling you. We'd like you to run for the legislature." He said, "We think that you'd make a great candidate for the state legislature.” I said, “I couldn't even get the goddamn sheriff's nomination you think I'm going to get the legislature nomination?" He said, "That was a whole different story ... they think that you're the type of person, the calibre of person, that would make a good legislator."

I said, "This is crazy." If [he] hadn't called me, I would have never thought about it. (Reeher 2006: 55)

Attempts to map the plurality of people in parliament or the legislature have also generated various empirical typologies that seek to differentiate between politicians, both in terms of their pre-political pathways or trajectories and their behaviour once they enter the legislature (Barber 1965; Headey 1974; Searing 1994; Tiernan \& Weller 2010; Weller \& Grattan 1981). These studies find that some politicians are more interested in advocacy, while others are more administratively minded. Some are ambitious, but many are content just to watch the drama. Congruent with theoretical models outlined above, this perspective tends to privilege, or favour, certain types of politicians over others. James Barber (1965), for example, identifies four types of politician in his study of the Connecticut General Assembly 'Spectator', 'Advertiser', 'Reluctant', and 'Lawmaker' - of which he classifies the Lawmaker, who devotes undivided attention to the formulation and production of policy, as the one most responsible for getting things done. A similar dynamic is apparent in the 
extensive literature on the American presidency (for selected examples see Barber 1988, 1992; Hargrove 1998). This tendency aside, what these studies share is the emphasis on a plurality of people and experiences; politicians are not only Machiavellian competitors. Here is one of Reeher's (2006: 31) state legislators again:

When I was [a child] I became totally infatuated with John Kennedy running for president. I mean, I was interested in politics and my father had been a [local volunteer], but I don't think that was a major factor. I do believe my being turned on to John Kennedy - I know because I remember the conversations with myself convinced me that I wanted to be a politician as a career. And then in ... entering high school ... I fell in with the debating team and hooked up with a handful of other kids who were also Kennedy freaks, and were similarly determined to be politicians, and we decided we would all do this together. And three of that crew aside from myself, one is [a prominent political adviser], he was my debating team partner, and one is my legislature colleague and now my congressman.... And the third fellow is [a prominent] lobbyist. That little crew decided we were going to do this for our lives, and we all got involved in local politics [in my city]. For a couple of years, our main activity was recruiting high school and college students to work in local campaigns, and we had a very substantial impact on local politics doing that....

The lesson is that behind the public persona, politicians are real people with personal histories that speak to their hopes and fears, doubts and convictions, pleasures and pains.

\section{Commitment to Service}

In their book Stealth Democracy Hibbing and Theiss-Morse (2002) found that survey participants in the US were generally uninterested in politics and policy-making. For the most part, they were happy to leave decision-making to others, providing they could trust 
politicians to act in their interests. If this verdict is right, it should come as no surprise that the public is primarily concerned about the motivations of their leaders - do they intend to serve the public good or are they in it for personal gain? - and that as a result it becomes easier to understand why politicians spend so much time trying to convince us that they can be trusted. Perversely, it is difficult to explain that most politicians believe they have good intentions. Reeher (2006, p. 12), for example, is bemused that academics or members of the media rarely believe that politicians are primarily acting out of a sense of the public good, or that they are making efforts to discover that good and what it requires in terms of policy. Academic and former Canadian Minister, Richard French (2012: 534), goes further by accusing both political scientists and theorists of fundamentally misunderstanding the essence of what a life dedicated to politics means. Echoing Weber, he makes a case for treating public office as an exceptional form of service unlike almost all other occupations. Conversely, politicians often deride each other's motives and intentions. As noted above, the adversarialism of the democratic system encourages this rhetoric, deepening the distrust. In an ideal scenario, politicians would regain and maintain public confidence by telling the truth. And yet, as classical critiques of democracy highlight, rather than uncomfortable truths we often prefer our politicians to tell us what we want to hear: we require them to 'wear masks' (Runciman 2008, p. 196).

Beneath the mask, an expressed intrinsic reward that comes from a life of public service is a feature of politician-centred studies from around the world. James Walter's (2006) cohort study of Australian politicians finds that they tend to believe that virtuous motivations led them to enter politics and that public scepticism towards politicians is undeserved, and that political work is not well understood. Similarly, Reeher's (2006, pp. 59-60) study of US state legislators finds that most politicians have a deeply felt commitment to civic engagement, which, in their minds, necessarily entails active political participation and leadership, while 
their continued involvement in politics highlights a belief that they can, and do, make a difference. That is not to suggest that politicians are saints. Rather, as political scientist and former Leader of the Opposition in Canada, Michael Ignatieff (2013, p. 8), reflects, holding office can be so thankless that if a politician doesn't acquire some sense of service or vocation they simply won't survive:

From pretending to serve, you may surprise yourself by actually doing so. Indeed, you have to acquire some sense of service if you are to survive at all. A politician's job can be so thankless at times that if you don't acquire a sense of vocation you turn yourself, by stages, without realising it, into a hack.

Along with a general commitment to service, most politicians express a great love for their work. They may not always enjoy it, but most miss it when they leave. Anthony King's (1974, p. 110) portrait of British politicians finds that they liked having 'front row seats'. They liked being there - where power resides and where decisions are made - and feeling like they are part of it all.

... For me, the sense of history, and just working in the building, is really critical. I've always worked for antipoverty agencies or no-profit agencies, and the structures I've worked in and the circumstance in the buildings have all been real low-rent, ugly, unattractive, no amenities. And it isn't really the amenities, it's the reality that I'm in this beautiful building where all these people have been before me and all these people will go after me, and for some tiny slice of time, I am one of them. And that's just thrilling to me. (Reeher 2006: 69).

And, while their views and ideologies varied, they agreed that their work had frustrations (constituents, party politics and family pressures), but also opportunities (friendships and experiences). 
While the reasons and meanings attached to service may vary from place to place we can infer that an overriding sentiment common to most politicians is a belief that they enter politics to act on behalf of others and that this action produces tangible outcomes despite the fact that, to channel Weber, the process is often painfully slow, as this quote illustrates:

The most important thing is to have a clear view about what you want to change. Politics is a relentless business. Running government is a relentless business and you could wake up every morning and let it run you and not achieve what you set out to do or you can wake up every morning and say, 'I'm going to run it. I got into this business to achieve the following things and I'm going to crash through and I'm going to push and I'm going to achieve them.' Lots of things about our system - the shortness of the news cycle, some of the cynicism about politics, the bigness of the bureaucracy - lots of things conspire to defeat that. You've just got to have the wherewithal each and every day to say, 'No, I'm running it, its not running me, and I'm sticking in there to achieve what I set out to achieve at the start' (Tiernan and Weller 2010, p. 319).

Cynics may maintain that these reflections about the intrinsic joys of serving are nothing more than further proof that politicians are, at best, insincere and hypocritical and, at worst, outright liars. However, I prefer to follow Donald Searing's (1994, p. 389) argument that we cannot solely judge the motivations of politicians on models drawn from their actions; that assumptions based entirely on socialisation or utility-maximisation, for example, are no substitute for empirical study. However, if we accept the empirical observations of this literature we must also accept the limits of good intentions in the practical world of political affairs (what Medvic (2013, pp. 10-13 refers to this as the 'Principled-and-Pragmatic Trap'). The problem, in this view, is that while the public prefers politicians who stay true to their 
beliefs, they also bemoan ridged partisanship and the unwillingness of leaders to reach compromises that advance the public good.

\section{Costs and Rewards}

One of the reasons why politicians see their involvement in politics as a form of service is the costs involved, which, echoing Weber, they tend to attribute to the workload demanded by legislative life. Recognising the impact of their heavy workload is an often-cited defence of the people who hold public office. Work demands feature heavily in accounts of ministerial life, as described by Bruce Headey (1974), Weller and Grattan (1981) and Tiernan and Weller (2010), who investigated role perceptions amongst ministers in Britain and Australia. They found that ministers in particular are time-poor, necessitating compromises that enable them to manage the burden of ministerial work. This view is echoed by R.A.W. Rhodes' (2011) recent study of everyday life in British ministries. Rhodes presents a vision of a departmental 'court' under siege, beset by perpetual crisis:

The key task of the departmental court is to cope. Coping is not a dramatic activity. It is surprisingly ordinary. Private offices exist to domesticate trouble, to defuse problems, and take the emotion out of crisis ... What we have in Whitehall is 'willed ordinariness'. These everyday routines are unquestioned, to a degree unrecognisable (Rhodes 2011, pp. 161).

Like Rhodes, Matthew Mahler's (2011) portrayal of a congressional election campaign in America depicts a world shaped by the collective rituals of everyday political life: the culmination of mundane routines, strategy sessions, phone calls to colleagues, interactions with constituents, press appearances and fundraisers. These reflections are not glamorous they tend to occupy only short spaces in memoirs if they are mentioned at all - but, following Weber, they do provide a sense of what it is like to slowly bore 'through hard boards'. 
The punishing nature of political work is also a theme strongly emphasised by the few politicians who write in defence of their occupation (see Lieberman 2000; McDonough 2000; Volgy 2001; Ignatieff 2013). American academic and Mayor Thomas Volgy (2001, pp. 87111) describes politics as a series of endless conflicts between public officials and private spouses over 'quality time'. He paints a picture of long hours (6 am to mid-night), busily spent responding to constituent needs, fashioning policies and attending meetings, media events, dinners and fundraisers:

A year after I became mayor, I was taken out to lunch by a friend who had worked on several of my campaigns. Her purpose in getting together with me was to tell me that, since becoming mayor, I had become inaccessible to my friends. She wanted to let me know that I was no longer available to them the way that I had been before becoming mayor, and she wanted to know why I was deserting them. She told me that I was letting them down by not spending more time with them, and she felt that they were no longer "good enough" for me.

I tried to explain to her how little time there was in the day for a personal life. I don't think she believed me. We parted strangers. (Volgy, 2001: 109-110)

In a similar vein, Ignatieff (2013, p. 53) describes campaigning for Prime Minister in Canada as a sustained physical challenge, necessitated by the requirement to travel in particular, made all the more demanding by the fact that he was are 'on show' all of the time:

Once you enter politics, you are always on show. You never jump a queue, you never get impatient with a driver or a waitress or a check-in clerk. You never lose your temper. You never fail to light up when someone comes over for a picture or an autograph. You surrender the entirety of your private life for the duration. People are watching. 
This emphasis on the loss of privacy strongly echoes Arendt's view that Action in the public sphere has a transformative affect on the individuals concerned.

One consequence of this, politicians admit, is that the job provides a constant battle to stay true to themselves and their sense of who they are. They confess that the trade-offs or compromises required to achieve political aims challenge the fundamental beliefs and values they hold:

Within a year of entering politics, I had the disorientated feeling of having been taken over by a doppelganger, a strange new persona I could barely recognize when I looked at myself in the mirror (Ignatieff 2013, p. 80).

A minority claim to have never experienced situations of ethical dilemma when faced with tough decisions, but, echoing Lord Acton's famous maxim about the capacity of power to corrupt absolutely, the more common story is that these situations are unavoidable:

People in public office, especially at local and state levels of government, are squeezed by many of the same financial and family pressures that so many others are. But unlike most people, politicians have power, which can be worth something, and therefore they are faced with opportunities and ethical challenges others are not ... These are not always easy decisions. Throughout my public life I have struggled with them and watched political colleagues do the same (Lieberman 2000, pp.51-52).

Whilst politicians may not always enjoy political life, most miss aspects of it when they leave. Even those who entered reluctantly or had no initial interest often become enthralled by the position. In this respect, what Rhodes (2011) and others refer to as the mundane rituals of everyday political life can be the cause of regular complaint, while also being the things they miss the most once their career is over. Peter Riddell's (1996, p. 8) British politicians 
talk about politics as a bug: 'once you get it, it is very difficult to shake off.' Even when they do leave most maintain more than a casual interest and some find employment in related sectors. As above, the ability of people to make a career out of politics and ancillary political positions is often central to the popular critique of political figures. The riposte is that politics can be both a career and a passion; by virtue of their participation many claim to forego higher salaries and better perks on offer in other professions.

\section{Contingency and Uncertainty}

A common complaint about politicians found in surveys is that they spend too much time talking, arguing and debating and not enough time getting things done (for discussion see Evans, Stoker and Nasir 2013). Perversely, what emerges from the literature on and about politicians is that a life in politics is persistently beset by problems of contingency. In his book the Life and Death of Democracy, John Keane (2009, pp. 51-3) argues that the Athenian practice of rotating leadership, and the active participation of large portions of the city of Athens in the affairs of state, provided citizens with an awareness of the contingency of events and reminded people of the frailty of human endeavours and the difficulties associated with public decision-making - what he calls 'the ubiquity of perplexity'. In contrast, politicians today often lament that despite rising public scrutiny their work, and the extent to which chance (or Fortuna) shape outcomes, is not well understood by those looking in from the 'outside'. Indeed, they often profess to be just as frustrated about their inability to achieve desired results and claim that the constraints they work under can only be fully appreciated once you are on the 'inside'. Moises Naim (2013), formerly a cabinet minister in Venezuela, summarises this point in the Preface of The End of Power when recounting a discussion with Joschka Fischer, one of Germany's most popular politicians and a former vice chancellor and foreign minister: 
"Since I was young, I was fascinated and allured by power," Fischer told me. "One of my biggest shocks was the discovery that all the imposing government palaces and other trappings of government were in fact empty places. The imperial architecture of governmental palaces masks how limited the power of those who work there really is."

The extent to which the ability of politicians to wield power is 'decaying' is a feature of Naim's work but it is also reflected in the 'gap' view of anti-politics that emphasises the changes made to our political systems by neo-liberal reforms in particular. While this view may be correct, it is also no doubt true that leaders have always bemoaned the fact that their authority is to some extent contingent on factors outside their control. So, while politicians implicitly believe in their own agency, as Naim and others illustrate, what also emerges from these accounts of political life is a sense of powerlessness. Echoing the 'trap' account of antipolitics, for many, this paradox drives much of the frustration leaders and their publics feel towards politics.

The perpetual uncertainty that politicians experience about the intentions of voters, constituents, colleagues and opponents is a central theme in most politician-centred studies and this has particular implications for how politicians experience their different roles. Politicians often cite resource constraints and the malicious influence of external actors as reasons for why they find it difficult to get things done. This depiction of policy-making as a form of bargaining, where networks of policy actors engage in an interdependent process of governance, is a feature of Rhodes' (2011) and Tiernan and Weller's (2010, pp. 90-1) account of ministerial life, where the euphoria of winning government is quickly tempered by ministers' realisation of their relative unpreparedness and the complexities of policy-making, as this quote highlights: 
You have just finished the election campaign, you are necessarily physically tired and emotionally a bit spent from campaigning itself and then the volume strikes you in terms of the new briefing material, the commencement of the implementation of your election promises, and inevitably, there is just a pack of stuff that is gathered during the caretaker period but need a ministerial sign-off and there is six weeks of that waiting for you ... The[re is an extraordinary] volume at the start and then you find ways of working through it and managing it (Tiernan and Weller 2010: 78).

The regular rotation of leadership is a core principle of democratic government. What is often overlooked is the effect this has on the people who are being rotated. It is common to accuse politicians of being too focused on opinion polling but for those members who do not occupy 'safe seats' constituency dynamics dictate whether or not they will be employed. In addition to complexity, Richard Fenno (1978, p. 13) finds politicians live with a high level of uncertainty as, aside from elections, they have few ways of checking whether constituents believe they are doing a good job. Fenno's (1978, p. 214) politicians live in different 'worlds': the legislative world of Washington and the constituency world of their electorate. In part, the tension between the relative isolation in which policy is made, and how voters receive it, generates this uncertainty. More recently, Ignatieff (2013, p. 141) describes these 'worlds' as the real world of human contact and the virtual world of blogs and tweets.

This distinction between the different 'worlds' that politicians inhabit also focuses our attention on the compromises and trade-offs politicians have to make, and the difficulty they have in determining how their choices are received by both their colleagues and constituents. That is, what their reflections about daily life reveal is that choices about how to allocate time and resources not only occur in a policy sense - one position over another - but also between which roles they privilege - legislative, representative or ministerial - and whose interests 
they pursue - personal, constituent, commercial or party. Given this, the impression created by the authors of these politician-centred studies is of how difficult and messy political work is in practice. Rather than being frustrated at how nothing seems to get done, an 'insider' view asks us to consider how miraculous it is that anything gets done at all.

\section{The Importance of Human Endeavour}

The above synthesis forms the basis of a practical defence of politicians and political work. When combined with the previous theoretical discussion, this defence offers a reappraisal of human endeavour to the purpose and function of politics. One response to questions about prevailing negative attitudes towards the figure of the politician is: 'someone has to do it', implying that they perceive their value to be ultimately connected with their willingness to participate, as this quote illustrates:

... I think of public service as a personal commitment to being an active participant in the political process and understanding that it is a responsibility rather than an opportunity.... I think it's a responsibility to lead. I think it's a responsibility to try and mould political thought... I come at it from the Left, but I don't think that it's that much different than somebody coming from the Right who may believe in public service. I see it as an activist role (Reeher 2006: 45).

Politicians believe they are central to a functioning representative democracy and, as such, popular critique can mean little unless the accuser is prepared to dirty their hands by standing for election. Michael Walzer, who is famous for his 'dirty hands' depiction of politics, also provides us with clues as to why, when reflecting on their work, politicians tend to privilege the 'insider' view. Walzer, (1987, pp. 33-34) argues that conventionally critics are outsiders; impartial, dispassionate, unbiased, objective and legal-rational. The alternative model is the local judge or connected critic who earns their authority through engagement - sometimes 
angry and insistent - not detachment. From this perspective politicians are critics who are already on the inside and so it should come as no surprise that outsider critique means little unless the accuser is prepared to risk dirtying their hands by becoming an insider themselves. For them, only the 'insider' was prepared to follow the question 'Could you do a better job?' with action. Similarly, many politicians argue, only an 'insider' appreciates the inherent pragmatism of the 'numbers game' - be it during an election, when forming and maintaining government or when seeking to pass legislation.

Human endeavour, defined by the willingness of politicians to participate, is often overlooked in discussions about politics, anti-politics and political leadership. It is certainly not the lesson most commonly drawn from classic political leadership models that contemporary scholars tend to interpret as either endorsing democratic elitism or advocating participatory or deliberative reform. Others, as Kane and Patapan (2012, pp. 23-9) highlight, lament the absence of leaders, in the mould of a Lincoln or a Mandela, who have the right character and moral fibre. However, whether pursing interests or ideals, collective or individual goals, endeavour is implied. Similarly, while we often distinguish between 'good' and 'bad' types of endeavour - often referred to by their synonyms ambition and aspiration - this distinction, while plausible in theory, is unmanageable in practice, where motivations and intentions are fluid, shifting and responding to the trajectory of a political life. Moreover, public faith in individual leaders is similarly variable, with Lincoln, who is now immortalized as one of democracies greatest heroes, vilified in his lifetime in much the same way that politicians are today (Kane \& Patapan 2012, p. 165).

While the rampant ambition of leaders is an oft-cited cause of anti-politics, other commentators and theorists lament the limited ambitions of public office holders and claim they have no grand vision or set of ideals that they seek to realise. In practice, the response is 
inevitably the same: 'Could you do a better job?' And, if so, 'Why don't you run?' So that my meaning is clear, by emphasising the value of endeavour I am not advancing a consequentialist defence of political action that serves to exonerate all political behaviour; politicians often cite the unacceptable conduct of sitting MPs as a catalyst for their decision to contest. Moreover, I do not mean to disguise that the rise of the career politician disproportionately favours a certain type of candidate (see Norris 1997). Rather, as the earlier discussion of Arendt's conceptualisation of Action and Weber's emphasis on the practical value of 'boring through hard boards' illustrates, in a world in which fewer people join parties, leaving a diminishing pool of potential candidates, a reappraisal of endeavour highlights that it is one of the great strengths of our representative democracies that those who believe they can and are able to make a difference choose to do so.

Those who remain bent on blaming politicians for all of society's ills will no doubt argue that this article merely offers further proof that politicians rarely say what they mean or mean what they say (Runciman 2008, p. 197). This view is not only regularly cited by critics of politicians, but also by leaders who portray themselves as above politics, thus shaking off the stereotype of corruption and hypocrisy that besmirches the group. As outlined, politicians are often the most vocal critics of politicians, thus reinforcing Peter Riddell's (2010) argument that, if we believe in democratic government, we may sometimes have to defend them, even 'in spite of themselves'. In countries and eras where politics is not a 'profession', this sort of appeal to anti-politics by politicians preferring to identify themselves with their true vocation - priest, school teacher, doctor, lawyer or business person - may have some justification. However, this usually does not exclude them from group critique, even if they are afforded individual honour and respect. In turn, by recognising the essential familiarity - temporally and spatially - of popular disillusionment with politicians, we can appreciate just how misplaced much of this sentiment really is. 


\section{Conclusion}

The tension between leadership and popular sovereignty, where all people are equal, confronts all politicians who serve in democratic governments even if the nature of this tension varies over time. As politicians concede, decision-making creates winners and losers, and it is impossible to make everybody happy, although many claim to try. While this concession serves as a practical justification for their shortfalls, it is also inevitably disappointing (Dunn 2005). Mostly because, as Carl Schmitt's (2007) famous critique of democratic government highlights, the process of deciding is usually messy, subject to petty whims and trite disagreements, no one gets everything they want and some get more than others. Conversely, following Crick's (2000) reasoning, if the alternative is coercion, coups and warfare, perhaps we should embrace the compromises and endless negotiation required by the process of representative government, and either be more tolerant of the human failings of political leaders or run for public office ourselves.

My objective in this article was to explore the empirical findings of politician-centred studies from around the world and consider what they offer to the literature on anti-politics and the demonization of politicians. Based on this 'insider' view of political life, I presented a practical defence of politicians, that, aside from being analytically important to the antipolitics discussion, forms a counter narrative designed to temper the cycle of naive hope and cynical despondency that democratically elected politicians attract (Kane \& Patapan 2012, p. 9). I have avoided prescriptive ideals and normative definitions of what a politician should be, preferring instead to focus on democracy as it is practiced, and to see it through the eyes of those who practice it. In doing so, I illustrated that, as opposed to the homogenised disdain with which politicians as a group are often subjected, different types of people enter politics and they have varying ambitions and agendas. I showed that, contrary to the perception of rampant self-interest, politicians' think highly of the motivations that led them to the 
legislature and claim that public service offers intrinsic rewards. I argued that we underestimate the fact that political life incurs great personal costs to the people involved, including to family, health and to business and professional careers. I also highlighted the endless problems of contingency and uncertainty that plague all policy-makers; an awareness of which is often simplified in public debate, especially by politicians.

Rather than placing blame with either 'demand' or 'supply' side perspectives, I maintained that our sense of unease at the manner in which politicians go about their job partly reflects our own discomfort with their function and our unwillingness to undertake the task ourselves. In doing so, I sought to revive a discussion about human endeavour by employing Roosevelt's argument that the value of politicians stems, in part, from their willingness to participate. Revaluing endeavour allows us to reclaim a degree of respect for the people who occupy public office - be it in the past, present or the future - and permits us to acknowledge that, while we may not always like who politicians are, or the ways in which they operate, representative democracy does not function without them.

Acknowledgments: I would like to thank David Marsh, John Boswell, John Kane, Dennis Grube, Brendan McCaffrie and participants at the University of Canberra's Governance Research Forum for comments on earlier versions of this paper. Any errors are of course my own.

\section{References}

Arendt, H., 1958, The Human Condition, The University of Chicago Press, Chicago.

Arendt, H., 1961, Between past and future: Six exercises in political thought. London: Faber and Faber.

Arklay, T., Nethercote, J., and Wanna, J., 2006, 'Preface', in T Arklay, J. Nethercote and J. Wanna, eds. Australian Political Lives. Canberra: ANU E Press, xi-xiii. 
Bamberg, M., and Andrews, M., eds. 2004. Considering Counter-Narratives: Narrating, Resisting, Making Sense, John Benjamins: Amsterdam and Philadelphia.

Barber, J.D., 1965. The Lawmakers: Recruitment and Adaptation to Legislative Life. New Haven and London: Yale University Press.

---- 1988. Politics by Humans: Research on American Leadership. Durham and London: Duke University Press.

---- 1992. The Presidential Character: Predicting Performance in the White House, 4th edn, New Jersey: Prentice-Hall.

Chambers, S., 2003. Deliberative democratic theory. Annual Review of Political Science, 6(1), 307-326.

Crick, B., 2000. In Defence of Politics, Fifth edn. Great Britain: Continuum.

Dryzek, J.S., 2000. Deliberative democracy and beyond: liberals, critics, contestations. Oxford: Oxford University Press.

Dunn, J., 2005. Setting the People Free: The Story of Democracy. London: Atlantic Books.

Evans, M., Stoker, G., and Nasir, J 2013. How do Australians imagine their democracy? Australian survey of political engagement findings 2013. Canberra, Australia: Australian and New Zealand School of Government: http://www.governanceinstitute.edu.au/magma/media/upload/ckeditor/files/DEMOCRACY\% 20REPORT-\%20UPDATED\%20VERSION-27-6-13.pdf (accessed 19/11/2013).

Fenno, R., 1978. Home Style: House Members in their Districts. Boston and Toronto: Little Brown and Co.

Flinders, M., 2010. In Defence of Politics. The Political Quarterly, 81(3), 309-326.

---- 2012a. Defending Politics: Why Democracy Matters in the Twenty-First Century. Oxford and New York: Oxford University Press. 
---- 2012b. The demonisation of politicians: moral panics, folk devils and MPs' expenses. Contemporary Politics, 18(1), 1-17.

---- 2012c. Debating demonization: in defence of politics, politicians and political science. Contemporary Politics, 18(3), 355-366.

French, R. D., 2012. The Professors on Public Life. The Political Quarterly 83(3), 532-540.

Fung, A., and Wright, E.O., 2001. Deepening democracy: innovations in empowered participatory governance. Politics and society, 29(1), pp. 5-42.

Gutmann, A., and Thompson, D.F., 1996. Democracy and disagreement. New Haven: Harvard University Press.

Hargrove, E.C., 1998. The president as leader: Appealing to the better angels of our nature. Lawrence: University Press of Kansas.

Hatier, C. 2012. 'Them'and 'us': demonising politicians by moral double standards. Contemporary Politics. 18(4), 467-480.

Hay, C., 2007. Why We Hate Politics. Cambridge: Polity Press.

Hay, C., 2009. Disenchanted with democracy, pissed off with politics. British Politics, 4(1), 92-99.

Hay, C., and Stoker, G., 2009. Revitalising Politics: Have We lost the Plot? Representation, $45(3), 225-236$.

Headey, B., 1974. British Cabinet Ministers: The Roles of Politicians in Executive Office. London: George Allen and Unwin Ltd.

Hibbing, J. R., and Theiss-Morse, E., 2002. Stealth democracy: Americans' beliefs about how government should work. New York and Cambridge: Cambridge University Press.

Ignatieff, M., 2013. Fire and Ashes: success and failure in politics. Cambridge, Massachusetts and London, England: Harvard University Press. 
Kane, J., and Patapan, H., 2012. The Democratic Leader: How Democracy Defines, Empowers, \& Limits its Leaders. Oxford: Oxford University Press.

Keane, J., 2009. The Life and Death of Democracy, New York and London: Simon and Schuster.

King, A., 1974. British Members of Parliament: A Self Portrait. London and Basingstoke: The MacMillan Press Ltd.

Lieberman, J.I., 2000. In Praise of Public Life. New York and London: Simon and Schuster.

Mahler, M., 2006. Politics as a Vocation: Notes Toward a Sensualist Understanding of Political Engagement, Qualitative Sociology 29(3), 281-300.

---- 2011. The Day Before Election Day, Ethnography, 12 (2), 149-173.

McDonough, J.E., 2000. Experiencing Politics. Berkeley, Los Angeles and London: University of California Press.

Medvic, S.K., 2013. In Defense of Politicians: The Expectations Trap and Its Threat to Democracy. New York and London: Routledge.

Naim, Moises. 2013. The end of power: from boardrooms to battlefields and churches to states, why being in charge isn't what it used to be. Basic Books.

Norris, P., ed. 1997. Passages to power: legislative recruitment in advanced democracies. New York: Cambridge University Press.

Reeher, G., 2006. First Person Political. New York and London: New York University Press. Rhodes, R.A.W., 2011. Everyday Life in British Government. Oxford and New York: Oxford University Press.

Riddell, P., 1996. Honest Opportunism : how we get the politicians we deserve London: Indigo.

---- 2010. In Defence of Politicians: In Spite of Themselves. Parliamentary Affairs, 63(3), $545-557$. 
Rudd, A., 2009. In Defence of Narrative. European Journal of Philosophy, 17(1), 60-75

Runciman, D., 2008. Political Hypocrisy: The Mask of Power, from Hobbes to Orwell and Beyond. Princeton: Princeton University Press.

Scalmer, S., and Hollier, N., 2009. I, Diarist: Examining Australian Politics from the 'Inside'. Australian Journal of Politics and History, 55(2), 170-189.

Schaap, A., 2012. Hannah Arendt and the Philosophical Repression of Politics. In J.P. Deranty and A. Ross, eds. Jacques Ranciere and the Contemporary Scene: The Philosophy of Radical Equality. London and New York: Continuum International Publishing Group, 145-166.

Schmitt, C., 2007. The Concept of the Political. Chicago: University of Chicago Press.

Searing, D., 1994. Westminster's World. Cambridge, Massachusetts and London, England: Harvard University Press.

Shamir, B., Dayan-Horesh, H., and Adler, D., 2005. Leading by Biography: Towards a Lifestory Approach to the Study of Leadership. Leadership, 1(1), 13-29.

Schwartz-Shea, P., and Yanow, D., 2012. Interpretive research design: Concepts and processes. London: Routledge.

Skowronek, S., 1993. The Politics Presidents Make: Leadership from John Adams to George Bush. Cambridge, Massachusetts and London, England: Harvard University Press.

Stoker, G., 2006. Why politics matters: making democracy work. Houndmills, England and New York: Palgrave Macmillan.

Tiernan, A., and Weller, P., 2010. Learning to Be a Minister: Heroic Expectations, Practical Realities, Melbourne: Melbourne University Press.

Uhr, J., 2005. Professional Ethics for Politicians? International Public Management Journal, $8(2), 247-262$. 
Volgy, T.J., 2001. Politics in the Trenches: Citizens, Politicians, and the Fate of Democracy. Tucson: The University of Arizona Press.

Walter, J., 2006. Politics, policy and change: biography and the age of uncertainty. paper presented to Australasian Political Studies Association conference, University of Newcastle, Australia, 25-27 September 2006.

Walzer, M., 1987. Interpretation and Social Criticism. Cambridge, Massachusetts and London, England: Harvard University Press.

Weber, M., 1978. Politics as a Vocation. In W. G. Runciman, ed. Max Weber: Selections in Translation. Cambridge: Cambridge University Press, 212-225.

Weller, P., and Grattan, M., 1981. Can Ministers Cope? Melbourne: Hutchinson Group.

Wood, M., and Flinders, M., 2012. From Folk Devils to Folk Heroes: Rethinking the Theory of Moral Panics. Moral Panic Studies Working Paper Series, 2012(2).

Wright, T., 2013. What is it about politicians? The Political Quarterly, 84(4), 448-453. 